УДК 339

\title{
КОМПАНІЇ-ЄДИНОРОГИ В МІЖНАРОДНОМУ БІЗНЕСІ: РЕГІОНАЛЬНО-ГАЛУЗЕВИЙ АСПЕКТ
}

\section{UNICORN COMPANIES IN INTERNATIONAL BUSINESS: REGIONAL AND SECTORAL ASPECTS}

\author{
Галахова Тетяна Олексіївна \\ кандидат економічних наук, доцент, \\ доцент кафедри міжнародного менеджменту, \\ ДВНЗ «Київський національний економічний університет \\ імені Вадима Гетьмана» \\ ORCID: https://orcid.org/0000-0002-0600-1886 \\ Євдоченко Олена Олександрівна \\ кандидат економічних наук, доцент, \\ доцент кафедри міжнародного менеджменту, \\ ДВНЗ «Київський національний економічний університет \\ імені Вадима Гетьмана» \\ ORCID: https://orcid.org/0000-0002-2021-4116 \\ Кислицина Ольга Володимирівна \\ кандидат економічних наук, \\ доцент кафедри міжнародного менеджменту, \\ ДВНЗ «Київський національний економічний університет \\ імені вадима Гетьмана» \\ ORCID: https://orcid.org/0000-0003-0117-0274 \\ Halakhova Tetiana, Yevdochenko Olena, Kyslytsyna Olga \\ Kyiv National Economic University named after Vadym Hetman
}

\begin{abstract}
Стаття присвячена дослідженню сутності та ключових особливостей компаній-єдинорогів - інноваційних стартапів, вартість яких складає 1 млрд. дол. США і більше. В статті підкреслено, що компанії-єдинороги це компанії, які не тільки відповідають кількісній оцінці в 1 мільярд доларів, але й мають такі характеристики як трансформаційний галузевий корпоративний вплив, значний інноваційно-креативний та соціокультурний вклад у глобальний бізнес-розвиток у довгостроковій перспективі. Зважаючи на зміни глобального бізнес-середовища, авторами виділено основні характеристики компаній-єдинорогів сьогодні: підривні інновації, орієнтація на кінцевого споживача (В2С), суттєва зміна технологічної парадигми, заснована на комісії модель заробітку, найпопулярніший ринок - ритейл та електронна комерція. За результатами регіонально-секторального аналізу визначено, що більшість єдинорогів походить з США та Китаю та базується у високо інтегрованих містах категорії Alpha та Beta; суттєво превалює сектор фрінтех, програмного забезпечення та IT-послуг, електронної комерції. В статті також узагальнено ключові трансорормаційні виклики для розвитку компанійєдинорогів у часи пандемії COVID-19: споживання з дому, роботу з дому та навчання 3 дому.
\end{abstract}

Ключові слова: стартап, компанія-єдиноріг, інновації, високоінтегровані міста, трансформаційні виклики.

Статья посвящена исследованию сущности и ключевых особенностей компаний-единорогов - инновационных стартапов, стоимость которых составляет 1 млрд. долл. США и более. В статье подчеркивается, что компании-единороги - это компании, которые не только соответствуют количественной оценке в 1 млрд. долларов, но и имеют такие характеристики, как трансформационное отраслевое корпоративное влияние, значительный инновационно-креативный и социокультурный вклад в глобальное бизнес-развитие в долгосрочной перспективе. Учитывая изменения глобальной бизнес-среды, авторами выделены основные характеристики компаний-единорогов сегодня: подрывные инновации, ориентация на конечного потребителя (В2С), существенное изменение технологической парадигмы, основанная на комиссии модель заработка, самый популярный рынок - ритейл и электронная коммерция. По результатам регионально-секторального 
анализа, проведенного в статье, определено, что большинство единорогов происходит из США и Китая и базируется в высоко интегрированных городах категории Alpha и Beta; существенно превалирует сектор фринтех, программного обеспечения и ИТ-услуг, электронной коммерции. В статье также обобщенны ключевые трансформационные вызовы для развития компаний-единорогов во времена пандемии COVID-19: потребление из дома, работа из дома и учеба из дома.

Ключевые слова: стартап, компания-единорог, инновации, високоинтегрированные города, трансформационные вызовы.

The article is devoted to the study of the essence and key features of unicorn companies - innovative startups, the value of which is 1 billion dollars USA and more. The author's definition of a unicorn company is proposed: these are avant-garde startup companies that implement innovative and creative business models different from traditional business, have significant potential and dynamics of development, attract highly qualified managers to the company's management, implement their activities based on advanced technological solutions and understanding of the global processes of digitalization, for effective development require a modern startup ecosystem and cost 1 billion dollars or more. In other words, such companies not only meet the $\$ 1$ billion quantification, but also have such transformational industry corporate influence, significant innovation-creative and socio-cultural contribution to global business development in the long run. Given the changes in the global business environment, the authors highlight the main characteristics of unicorn companies today: disruptive innovation, focus on the end user (B2C), a significant change in the technological paradigm, commission-based earnings model, the most popular markets are retail and e-commerce. According to the results of the regional-sector analysis, it was determined that the majority of unicorns come from the USA and China, suchn sectors as fintech, software and IT services, e-commerce significantly predominates. Taking into account the methodology of the Globalization and World Cities Research Network, the authors clustered the cities with the largest number of unicorn companies, It showed that most of them are based in highly integrated Alpha and Beta cities. The article also summarizes the key transformation challenges for the development of unicorn companies during the COVID-19 pandemic and outlines the transformational aspects of the development vector: home consumption will accelerate the development of e-commerce technologies, platforms and information and innovation applications; work from home intensifies the development of remote business systems, information and communication technologies and tools; learning from home will promote the development of educational technologies, massive online courses, corporate online universities.

Keywords: startup, unicorn company, innovations, highly integrated cities, transformation challenges.

Постановка проблеми. Розвиток стартапів у вимірі його багатовекторності, міждисциплінарності, міжгалузевого впливу та інших аспектів $€$ напрямом сучасних досліджень як теоретичного, так і практичного спрямування. В даній статті увагу буде приділено компаніям-єдинорогам - інноваційним стартапам, вартість яких складає 1 млрд. дол. США і більше. Дослідження вищезазначених компаній $є$ досить актуальним, оскільки такі компанії представляють собою успішні інноваційні бізнес-моделі з системою новітніх, унікальних та відмінних складових у порівнянні 3 діяльністю компаній у класичному розумінні бізнесвідносин та бізнес-середовища.

Аналіз останніх досліджень і публікацій. Дослідженню стартапів, їх класифрікації та систематизації присвячено багато праць як зарубіжних, так і вітчизняних фрахівців, серед яких доцільно виділити наступних: Бланк С., Дорф Б., Лі Ейн, Келлері Дж., Дж. ван Мойланд, Роса П., Рук Д., Салваторі А., Хенселек С., Ходгсон Л., Зайцева Л., Пирог О., Максимчук Я.

Виділення невирішених раніше частин загальної проблеми. Не зважаючи на постійно зростаючий інтерес дослідників до стартапів та їх ефрективних бізнес-моделей, умови глобального бізнес-середовища часто й швидко змінюються, вносячи корективи в попит на глобальному ринку, тим самим змінюючи регіонально-секторальну структуру стартапдіяльності та напрями й обсяги інвестування на даному ринку, що зумовлює актуальність подальших досліджень в даному напрямі.

Формулювання цілей статті (постановка завдання). Метою даної статті $€$ на основі теоретичного узагальнення та вивчення практичних аспектів розвитку стартапів виокремити особливості компаній-єдинорогів, надати визначення, враховуючи сучасні їх особливості, провести регіонально-секторальний аналіз та виявити ключові трансформаційні вектори їх розвитку в часи пандемії.

Виклад основного матеріалу дослідження. Як відомо, термін «єдиноріг» відносно стартапів вперше було використано у 2013 р. Ейлін Лі - засновницею стартап-компанії Cowboy Ventures. Даний термін спочатку характеризував певні «американські компанії, що займаються розробкою програмного забезпечення..., які розпочали свою діяльність у 2003 р., та оцінюються державними або приватними ринковими інвесторами на суму понад 1 млрд. дол. США» [1]. Таке визначення значно звужувало коло компаній-єдинорогів, навіть у 2013 р. їх налічувалося лише 
39. Наразі, за даними статистичної та аналітичної Dealroom, кількість стартапів, вартістю більше 1 млрд. дол. США на серпень 2021 р. дорівнює 1820. [2].

Відповідно даним бізнес-аналітичної платформи CB Insights стартап-компанії за вартісним критерієм можна класифікувати наступним чином (приклади наведені станом на 2021 рік) [3]:

- компанії-єдинороги (понад 1 млрд. дол. США. Snowflake - система хмарного зберігання даних, UiPath, Automate Anywhere - займаються автоматизацією бізнес-процесів, Circle випускає та підтримує інструменти для операцій з криптовалютами);

- компанії-декакорни (понад 10 млрд. дол. США - Uber, Twitter, WhatsApp, SnapChat, Pinterest, турецька платорорма електронної коммерції Trendyol);

- компанії куінквагінтакорни (від 50 млрд. до 100 млрд. дол.). За версією СВ Insights, такими є Didi Chuxing и JUUL Labs;

- компанії-гектокорни (понад 100 млрд.дол. США) - китайська компанія ByteDance - материнська компанія сервісу для створення і перегляду коротких відео TikTok, китайський стартап Kuaishou - мобільний додаток для обміну відео, американська фрінтех-компанія Stripe).

До основних характеристик сучасних компаній-єдинорогів можна віднести наступні [4]:

1. як правило, інновація має бути підривною - майже всі компанії - єдинороги суттєво змінили галузь, до якої вони належать. Одним 3 яскравих прикладів $€$ компанія Uber, яка достеменно змінила умови замовлення таксі. Крім того, єдинороги зберігають переваги першопрохідця, постійно вдосконалюючи продукт чи сервіс.

2. орієнтація на кінцевого споживача: майже 62\% єдинорогів - це продукти для В2С, крім того такі компанії намагаються зробити продукт чи сервіс простішим і доступнішим для покупців та користувачів.

3. суттєві зміни технологічної парадигми: 87\% продуктів - це програмне забезпечення, $7 \%$ - обладнання, а $6 \%$ - інші.

4. як правило, модель заробітку стартапа заснована на комісії. Так, при замовленні таксі $з$ кожної поїздки певний відсоток отримує водій. Така схема зарабітку характерна для 33\% єдинорогів.

5. Найпопулярніший ринок для таких стартапів - ритейл та електронна комерція, де $25 \%$ єдинорогів заробляють мільйони.

Зважаючи на вищезазначене, на нашу думку, визначення компаній-єдинорогів може бути представлене у більш широкому розумінні: компанії-єдинороги - це авангардні стартап-компанії, які реалізують відмінні від традиційного бізнесу інноваційно-креативні бізнес-моделі, мають значний потенціал та динаміку розвитку, залучають висококваліфрікованих управлінців в менеджмент компанії, реалізують свою діяльність на основі прогресивних технологічних рішень та розуміння глобальних процесів діджиталізації, для ефективного розвитку потребують сучасної стартап-екосистеми, і мають вартість 1 млрд. дол і більше. Компанії-єдинороги - це дуже успішні бізнес-моделі, проте не всі такі компанії можуть втримати свої конкурентні позиції на ринку у довгостроковій перспективі, і з часом можуть втратити цей статус. Зважаючи на вищезазначене, можна стверджувати, що компанії - єдинороги - це компанії, які не тільки відповідають кількісній оцінці в 1 мільярд доларів, але й мають такі характеристики як трансформаційний галузевий корпоративний вплив, значний інноваційно-креативний та соціокультурний вклад у глобальний бізнес-розвиток у довгостроковій перспективі.

У таблиці 1 представлена вибірка перших десяти компаній-єдинорогів за рейтингом СВ Insights.

Перше місце у рейтингу стартапів - єдинорогів за загальною вартістю згідно представлених даних CB Insights займає китайська компанія ByteDance [5] (залучено 7,44 млрд. дол. США), що була заснована у 2012 р. та пропонує контент-платорорми на основі технологій штучного інтелекту, зокрема TikTok, Vigo, Toutiao, TopBuzz тощо.

Друге місце займає калісрорнійська Stripe [6] (залучено 2,901 млрд. дол. США), що була заснована у 2010 р., - інноваційна онлайнплатформа для безпечної обробки платежів для онлайн-продавців.

На третьому місці у рейтингу СВ Insights каліфрорнійська компанія SpaceX [7] (залучено 6,539 млрд. дол. США), 2002 року заснування, що проектує, виробляє та запускає сучасні ракети та космічні кораблі.

Представимо ключові аспекти компанійєдинорогів у вимірі: критеріїв оцінки, регіонального та галузевого аналізу, трансорормаційного впливу пандемії COVID-19.

Згідно рис. 1 найбільша кількість компанійєдинорогів зосереджена у США, Китаї, Індії, Великій Британії, Німеччині, Ізраїлі, Франції, Канаді, Південній Кореї та Бразилії. Серед зазначених компаній можна чітко виокремити 
Топ-10 компаній-єдинорогів у 2021 р. за даними СВ Insights

Таблиця 1

\begin{tabular}{|c|l|c|c|l|}
\hline Позиція & \multicolumn{1}{|c|}{ Компанія } & $\begin{array}{c}\text { Вартість, } \\
\text { млрд. дол. США }\end{array}$ & Країна & \multicolumn{1}{|c|}{ Галузьссектор } \\
\hline 1 & Bytedance & 140 & Китай & Штучний інтелект \\
\hline 2 & Stripe & 95 & США & Фінтех \\
\hline 3 & SpaceX & 74 & США & Інше \\
\hline 4 & Klarna & 45,6 & Швеція & Фінтех \\
\hline 5 & Instacart & 39 & США & Логістика і поставки \\
\hline 6 & RevolutRevolut & 33 & Великобританія & $\begin{array}{l}\text { Система постачання, } \\
\text { логістика, доставка }\end{array}$ \\
\hline 7 & Nubank & 30 & Бразилія & Фінтех \\
\hline 8 & Epic Games & 28,7 & США & Інше \\
\hline 9 & Databricks & 28 & США & $\begin{array}{l}\text { Управління даними } \\
\text { та аналітика }\end{array}$ \\
\hline 10 & Rivian & 27,6 & США & Авто та транспорт \\
\hline
\end{tabular}

Джерело: складено авторами за даними статистичної та бізнес-аналітичної платформи CB Insights [3]

два масштабні лідери - США (близько 45\% всіх компаній-єдинорогів) та Китай (близько 21\% всіх компаній-єдинорогів).

У цьому контексті цікавим $є$ дослідження міжнародної консалтингової компанії PwC «Дослідження китайських компаній-єдинорогів» (2019р.) [8], в якому було виокремлено ключові конкурентні переваги китайських компаній-єдинорогів: інноваційні технології, висококваліфріковані таланти, інфрормація та аналітичні інструменти обробки даних, ефективний операційний менеджмент та реалізація сучасних маркетингових стратегій (рис. 2). 3гідно рис. 2 більшість компаній акцентували увагу на інноваційних технологіях та висококваліфікованих талантах як ключових конкурентних перевагах.

Регіональний аналіз розвитку стартапівєдинорогів демонструє наступні особливості:

- європейський ринок - лідерами по кількості стартапів $€$ Велика Британія, Німеччина, Франція;

- азійський ринок представлений такими країнами як Китай, Індія, Ізраїль та Південна Корея, зі значним лідируванням Китаю як у азійському вимірі, так і у глобальному;

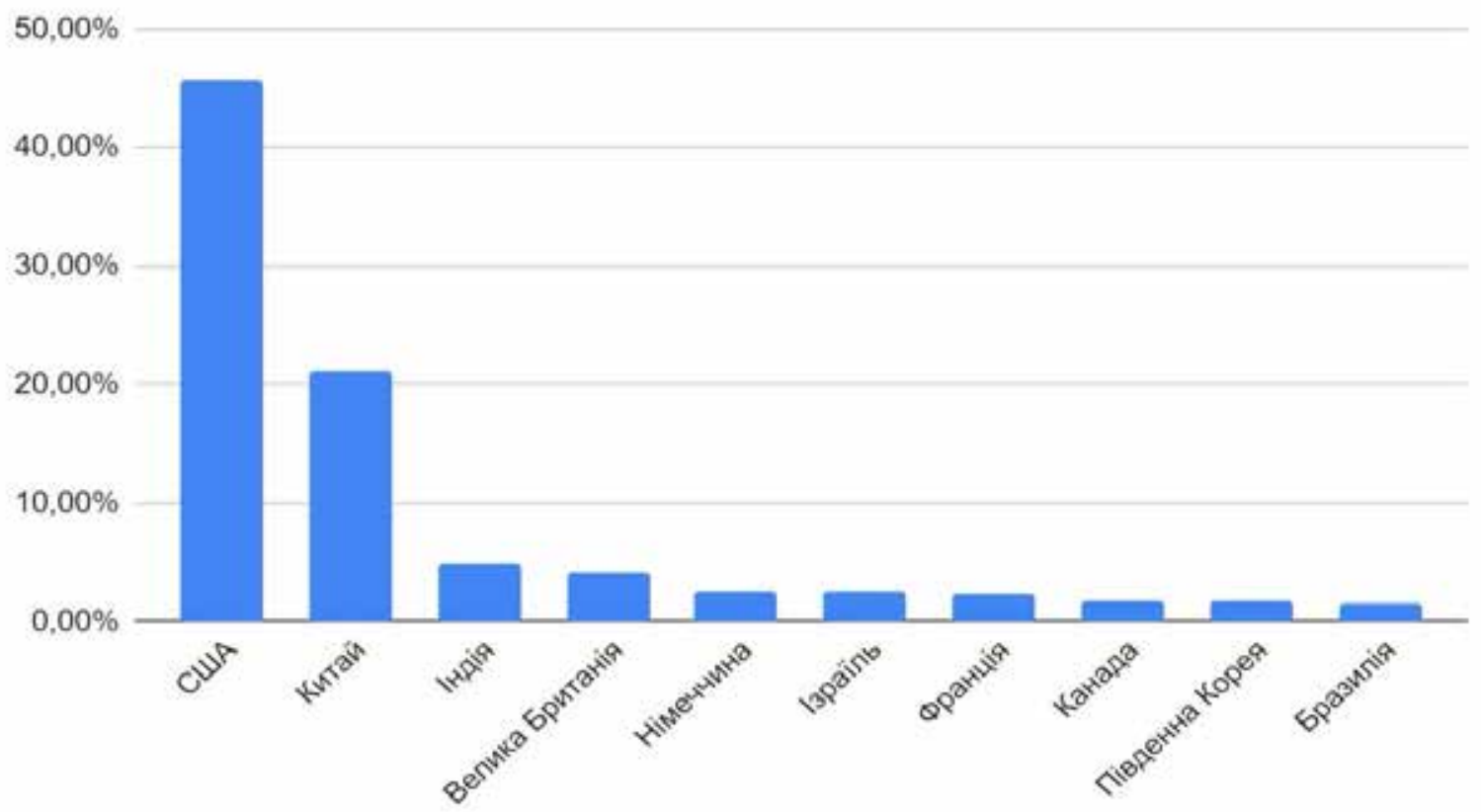

Рис. 1. Розподіл компаній-єдинорогів за країною походження, серпень 2021 року Джерело: складено авторами на основі статистичних даних бізнес-аналітичної платформи CB Insights [3] 


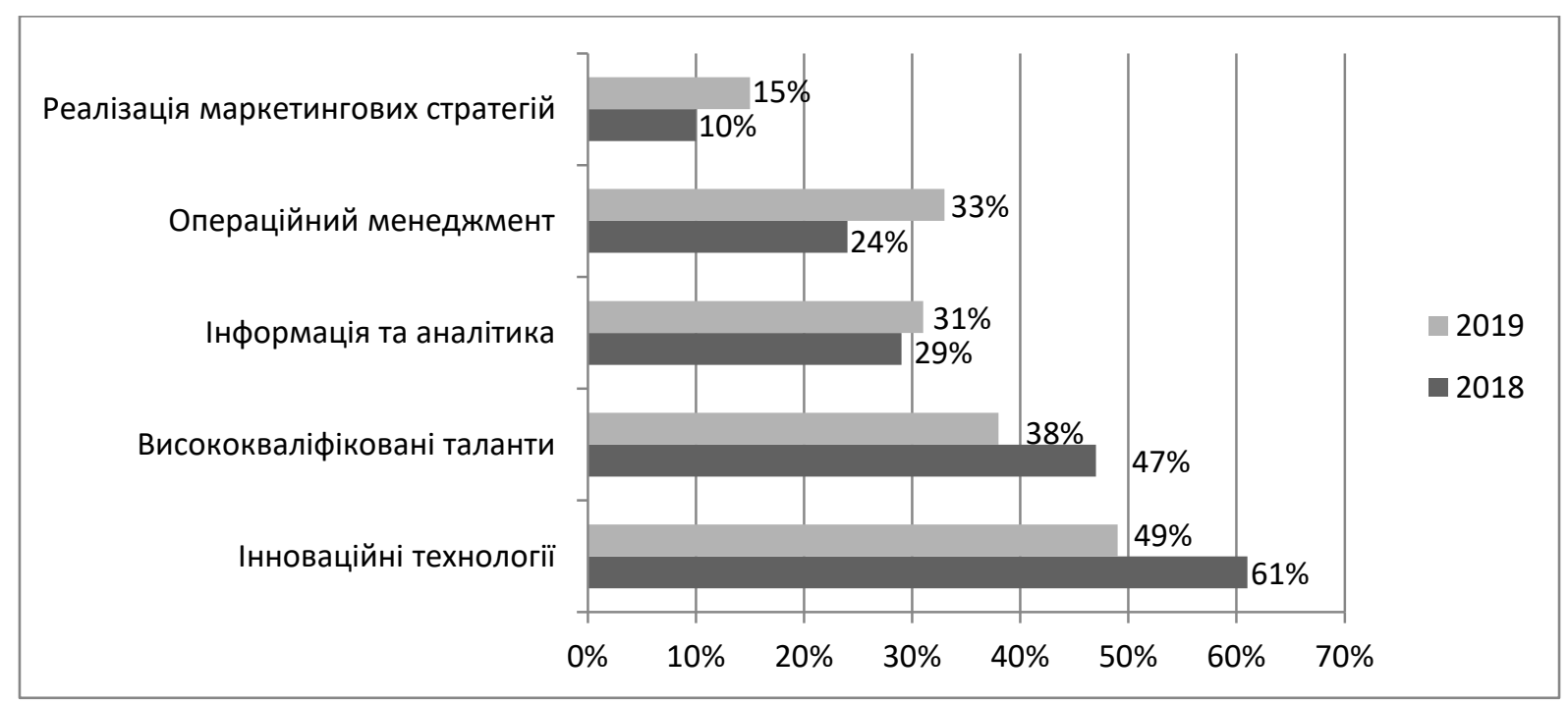

Рис. 2. Ключові конкурентні переваги китайських компаній-єдинорогів, 2018-2019 роки Джерело: [8]

- ринок Латинської Америки представлений Бразилією;

- ринок Північної Америки представляють США та Канада 3 домінуванням США у глобальному вимірі.

За даними аналітичної платорорми компанії PitchBook, найбільша кількість компаній - єдинорогів Європи на 2021 рік базується у Великобританії. Так, заснована у 2011 р. лондонська компанія Blockchain.com у 2021 р. залучила 420 млн., в результаті чого ії вартість зросла до 5,2 млрд. дол. США.

Також варто відзначити німецькі стартапи: 8 компаній - єдинорогів базуються в Німеччині, в тому числі Scalable Capital та Gorillas. Шведський стартап Klarna став найдорожчою компанією на європейському континенті, що орінансується венчурним капіталом [9; 10].

Якщо провести аналіз локалізації компаній-єдинорогів у вимірі міст, то можна відзначити переважне їх розташування у глобальних або високоінтегрованих розвинених містах, що мають ефрективну екосистему для розвитку ділових-відносин. Зауважимо, що глобальні міста - це масштабні впливові мегаполіси, що представляють собою значимі політично-дипломатичні центри (у таких містах розміщуються офріційні представництва глобально впливових організацій і структур) та відзначаються прогресивним технологічним, кроскультурним, інноваційнокреативним, фрінансово-інвестиційним, транспортно-логістичним розвитком. Глобальні міста розширюють горизонт розуміння світу «3 територіальними кордонами» до нового розуміння «місто-глобальний центр розви- тку». До глобальних міст сьогодні відносять Лондон, Нью-Йорк, Пекін, Париж, Сінгапур, Токіо та ряд інших [11].

Згідно методології аналітичного центру Globalization and World Cities (GaWC) Research Network, що був створений при Університеті Лафрборо (Loughborough University), найбільш впливові у глобальному вимірі міста були представлені наступними категоріями: Alpha, Beta, Gamma, High Sufficiency/ Sufficiency [12] (таблиця 2).

Враховуючи методологію Globalization and World Cities (GaWC) Research Network, представимо міста, де зосереджена найбільша кількість компаній-єдинорогів (таблиця 3).

Згідно таблиці 3 більшість компаній-єдинорогів базуються у високо інтегрованих містах, що відповідають категорії Alpha та Beta.

Проаналізувавши галузевий аспект діяльності компаній-єдинорогів, можемо відзначити, наступні тенденції: превалювання секторів фрінтех, програмного забезпечення та IT-послуг, електронної комерції серед інших прогресивних секторів. Сектори роздрібної торгівлі і туризму займають нижчі позиції серед представлених (рис. 3).

Щодо подальшого транссрормаційного розвитку компаній-єдинорогів, цікавим $€$ дослідження міжнародної консалтингової компанії Deloitte. Компанія Deloitte у своєму дослідженні «Високотехнологічні компаніїєдинороги та пандемія COVID-19: приватні та публічні компанії-єдинороги» [10] представила фрази пандемії COVID-19 та відповідні трассрормаційні зміни для розвитку компанійєдинорогів (таблиця 4). 
Таблиця 2

Методологія ранжування країн світу за рівнем інтеграційного впливу згідно Globalization and World Cities (GaWC) Research Network

\begin{tabular}{|c|c|c|c|}
\hline Інтеграційна роль & Категорія & Характеристика & Міста \\
\hline \multirow[t]{3}{*}{$\begin{array}{l}\text { Ключові центри } \\
\text { глобальної } \\
\text { економіки }\end{array}$} & Alpha++ & $\begin{array}{l}\text { Найбільш інтегровані } \\
\text { міста до світової } \\
\text { економічної системи }\end{array}$ & Лондон, Нью-Йорк \\
\hline & Alpha+ & $\begin{array}{l}\text { Високоінтегровані } \\
\text { міста, які доповнюють } \\
\text { Лондон та Нью- Йорк, } \\
\text { та задовольняють } \\
\text { потреби у ділових } \\
\text { послугах у Азійсько- } \\
\text { Тихоокеанському регіоні }\end{array}$ & $\begin{array}{l}\text { Гонконг, Сінгапур, } \\
\text { Шанхай, Пекін, Дубай, } \\
\text { Париж, Токіо }\end{array}$ \\
\hline & $\begin{array}{l}\text { Alpha } \\
\text { Alpha- }\end{array}$ & $\begin{array}{l}\text { Інші важливі світові міста, } \\
\text { які з'єднують найбільші } \\
\text { економічні регіони і } \\
\text { держави зі світовою } \\
\text { економікою }\end{array}$ & $\begin{array}{l}\text { Alpha: Сідней, Лос- } \\
\text { Анджелес, Торонто, } \\
\text { Мілан, Амстердам та ін. } \\
\text { АІрһа-: Сеул, Цюрих, } \\
\text { Дублін, Бостон, Лісабон } \\
\text { та ін. } \\
\end{array}$ \\
\hline $\begin{array}{l}\text { Пов'язують } \\
\text { регіони } \\
3 \text { глобальною } \\
\text { економікою }\end{array}$ & $\begin{array}{l}\text { Beta+ } \\
\text { Beta } \\
\text { Beta- }\end{array}$ & $\begin{array}{l}\text { Важливі світові міста які } \\
\text { сприяють встановленню } \\
\text { зв'язків їх регіону або } \\
\text { держави зі світовою } \\
\text { економікою }\end{array}$ & $\begin{array}{l}\text { Beta+: Вашингтон, Рим, } \\
\text { Берлін, Копенгаген, Тель- } \\
\text { Авів } \\
\text { Веtа: Київ, Денвер, } \\
\text { Абу-Дабі, Осло, Ріо-де- } \\
\text { Жанейро. } \\
\text { Beta-: Женева, Загреб, } \\
\text { Туніс, Філадельфрія, } \\
\text { Гуанчжоу }\end{array}$ \\
\hline \multirow[t]{2}{*}{\begin{tabular}{|l|} 
Пов'язують \\
інші міста \\
з регіональною \\
економічною \\
мережею
\end{tabular}} & $\begin{array}{l}\text { Gamma+ } \\
\text { Gamma } \\
\text { Gamma- }\end{array}$ & \begin{tabular}{|l} 
Світові міста, які \\
3'єднують менш регіони \\
і країни зі світовою \\
економікою, або важливі \\
світові міста, основною \\
функцією яких не є \\
надання передових \\
виробничих послуг. \\
\end{tabular} & $\begin{array}{l}\text { Gamma+: Роттердам, } \\
\text { Баку, Рига, Глазго, } \\
\text { Балтимор } \\
\text { Gатmа: Брістоль, } \\
\text { Анкара, Турин, Мальме } \\
\text { Gamma-: Порт Луїс, } \\
\text { Едмонтон, Лімасол, Солт- } \\
\text { Лейк-Сіті } \\
\end{array}$ \\
\hline & $\begin{array}{l}\text { High Sufficiency } \\
\text { Sufficiency }\end{array}$ & $\begin{array}{l}\text { Мають незначний } \\
\text { інтеграційний } \\
\text { вплив порівняно } 3 \\
\text { вищезазначеними } \\
\text { категоріями }\end{array}$ & $\begin{array}{l}\text { Краків, Улан Батор, Лідс, } \\
\text { Ереван } \\
\text { Нур-Султан, Лепциг, Берн }\end{array}$ \\
\hline
\end{tabular}

Джерело: складено авторами на основі [11, с. 66-67; 12]

Поділяючи думку Deloitte, хотілося б наголосити на ключових трансфрормаційні фракторах в діяльності та розвитку компаній-єдинорогів:

- споживання з дому (consuming from home (CFH)) спричинить активізацію розвитку технологій електронної комерції, платорорм та інфрормаційно-інноваційних додатків;

- робота з дому (working from home (WFH)) активізує розвиток дистанційних систем ведення бізнес-діяльності, інформаційнокомунікативних технології та інструментів;

- навчання 3 домy learning from home (LFH) сприятиме розвитку освітніх технологій, MOOC (massive online courses), корпоративних онлайн-університетів.
Втойжечаснеобхідно відзначити, що незважаючи на наслідки пандемії, як стверджує у своєму дослідженні PitchBook, у 2021 році кількість копаній-єдинорогів в Європі та Ізраїлі досягнуло 23 проти 8 у 2020 році, крім того ці компанії продовжують залучати рекордні обсяги венчурного капіталу: на даний момент було інвестовано 32,5 млрд. євро, що найімовірніше перевищить суму в 37,6 млрд. євро в минулому році [10; 15].

Висновки. Дослідження компаній-єдинорогів сьогодні $€$ вкрай актуальним напрямом як з теоретичної, так і з практичної точок зору. На нашу думку, визначення компаній-єдинорогів має засновуватися не лише на кількісному 
Таблиця 3

Міста з найвищими показниками концентрації компаній-єдинорогів, враховуючи методологію GaWC

\begin{tabular}{|c|c|c|c|c|}
\hline Perion & Країна & $\begin{array}{c}\text { Міста зосередження } \\
\text { компаній }\end{array}$ & $\begin{array}{c}\text { Категорія } \\
\text { міста } \\
\text { за GaWc }\end{array}$ & $\begin{array}{l}\text { Кількість } \\
\text { компаній }\end{array}$ \\
\hline \multirow{4}{*}{ Північна Америка } & \multirow{4}{*}{ США } & $\begin{array}{l}\text { Сан-Франциско } \\
\text { (Кремнієва долина) }\end{array}$ & Alpha- & 113 (3 739) \\
\hline & & Нью-Йорк & Alpha++ & 57 \\
\hline & & Чикаго & Alpha & 16 \\
\hline & & Бостон & Alpha- & 13 \\
\hline \multirow{4}{*}{ Східна Азія } & \multirow{4}{*}{ Китай } & Пекін & Alpha+ & 61 \\
\hline & & Шанхай & Alpha+ & 39 \\
\hline & & Шеньчжень & Alpha- & 17 \\
\hline & & Ганьджоу & Alpha- & 15 \\
\hline \multirow{2}{*}{ Південна Азія } & \multirow{2}{*}{ Індія } & Бенгалуру & Beta+ & 15 \\
\hline & & Ґурґаон & & 7 \\
\hline \multirow{2}{*}{ Західна Європа } & \multirow{2}{*}{ Велика Британія } & Лондон & Alpha++ & 22 \\
\hline & & Бристоль & Gamma & 5 \\
\hline \multirow{2}{*}{ Центральна Європа } & \multirow{2}{*}{ Німеччина } & Берлін & Beta & 11 \\
\hline & & Мюнхен & Alpha- & 4 \\
\hline Південно-західна Азія & Ізраїль & Тель-Авів & Beta+ & 12 \\
\hline Західна Європа & Франція & Париж & Alpha+ & 14 \\
\hline \multirow{2}{*}{ Північна Америка } & \multirow{2}{*}{ Канада } & Торонто & Alpha & 4 \\
\hline & & Ванкувер & Beta+ & 3 \\
\hline Східна Азія & Південна Корея & Сеул & Alpha- & 8 \\
\hline Латинська Америка & Бразилія & Сент Пауло & Alpha & 8 \\
\hline
\end{tabular}

Джерело: складено авторами на основі [11, с. 66-67; 13]

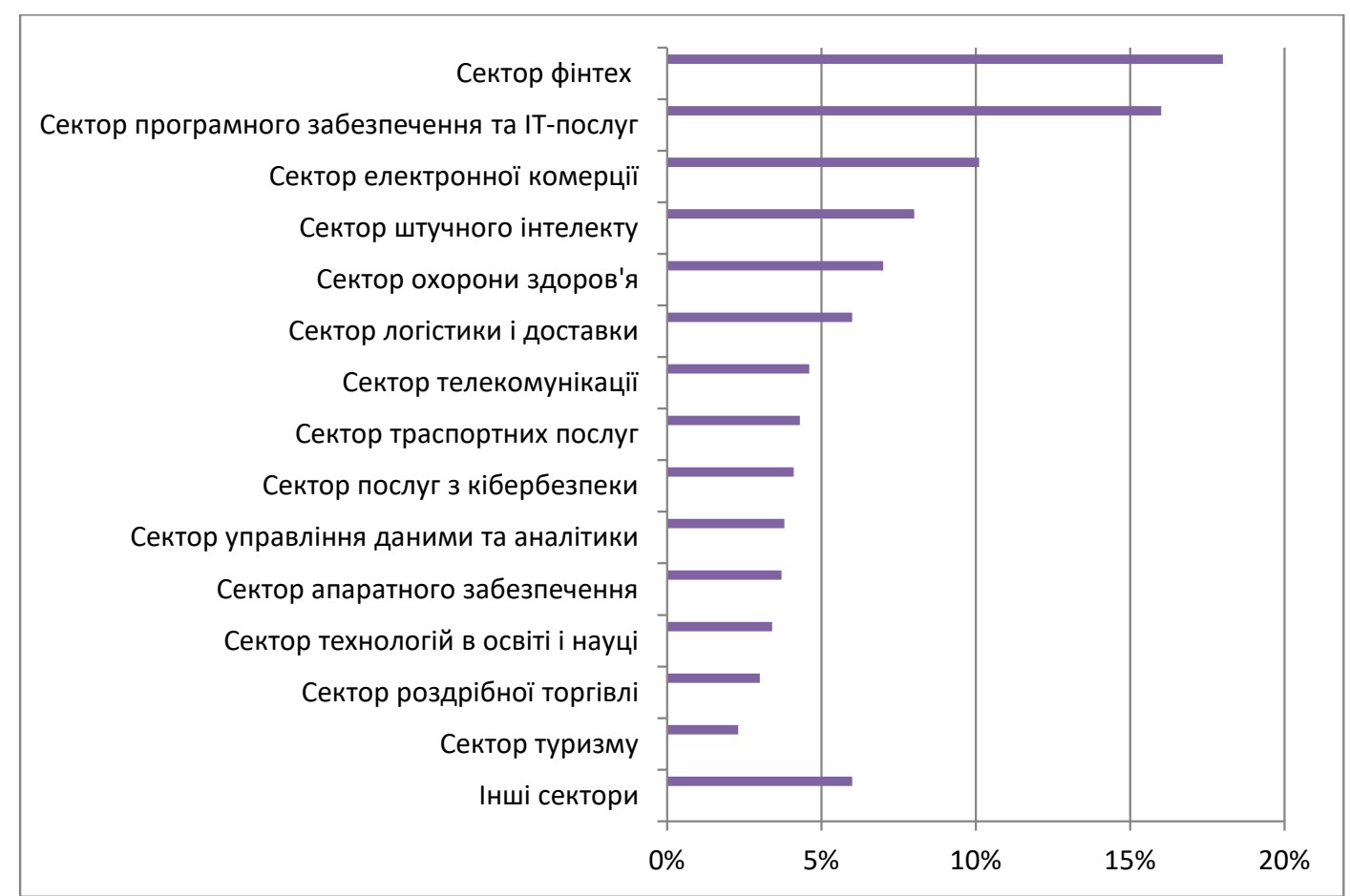

Рис. 3. Галузевий розподіл компаній-єдинорогів, 2021 рік

Джерело: створено автором на основі статистичних даних

бізнес-аналітичної платфрорми СB Insights [3] 
Таблиця 4

Трансорормаційні виклики бізнес-середовища для компаній-єдинорогів у розрізі фаз пандемії COVID-19

\begin{tabular}{|c|c|c|c|}
\hline \multirow{2}{*}{\begin{tabular}{|c|}
$\begin{array}{c}\text { Ключові категорії } \\
\text { аналізу }\end{array}$ \\
\end{tabular}} & \multicolumn{3}{|c|}{ Фази пандемії COVID-19 } \\
\hline & I фозаза & II фраза & III фраза \\
\hline & $\begin{array}{l}\text { Глобальний } \\
\text { карантин; } \\
\text { масштабні } \\
\text { обмежувальні } \\
\text { заходи. }\end{array}$ & $\begin{array}{l}\text { Послаблення карантинних } \\
\text { заходів; менш } \\
\text { обмежувальні заходи } \\
\text { з поступовим відкриттям, } \\
\text { продовження соціального } \\
\text { дистанціювання та } \\
\text { маскового режиму }\end{array}$ & $\begin{array}{l}\text { Вихід з карантину; } \\
\text { Вакцинація, набуття } \\
\text { імунітету та надання } \\
\text { кваліфрікованої медичної } \\
\text { допомоги }\end{array}$ \\
\hline $\begin{array}{l}\text { Приватні компанії- } \\
\text { єдинороги }\end{array}$ & \begin{tabular}{|l|} 
Відкриття нових \\
можливостей і \\
розвиток компаній
\end{tabular} & Значні бізнес-переваги & $\begin{array}{l}\text { Актуалізація проблеми } \\
\text { подальшого стратегічного }\end{array}$ \\
\hline $\begin{array}{l}\text { Публічні компанії- } \\
\text { єдинороги }\end{array}$ & $\begin{array}{l}\text { Криза бізнес- } \\
\text { діяльності }\end{array}$ & $\begin{array}{l}\text { Обмежені бізнес- } \\
\text { переваги }\end{array}$ & розвитку \\
\hline $\begin{array}{l}\text { Трансорормаційні } \\
\text { виклики бізнес- } \\
\text { середовища }\end{array}$ & $\begin{array}{l}\text { Дистанційна } \\
\text { робота/навчання, } \\
\text { діджиталізація } \\
\text { та кібербезпека, } \\
\text { розвиток } \\
\text { електронної } \\
\text { комерції }\end{array}$ & $\begin{array}{l}\text { - споживання з дому } \\
\text { (consuming from home } \\
(\text { (CFH)); } \\
\text { - робота з дому (working } \\
\text { from home (WFH)); } \\
\text { - навчання } 3 \text { домy } \\
\text { learning from home } \\
(\mathrm{LFH}) \text {. }\end{array}$ & $\begin{array}{l}\text { Об'єднання онлайн } \\
\text { та офрлайн формату } \\
\text { ведення бізнес-діяльності. } \\
\text { Переосмислення наявних } \\
\text { бізнес-моделей } \\
\text { та виникнення нових, } \\
\text { що відповідають реаліям } \\
\text { сьогодення, а також } \\
\text { враховують ймовірні } \\
\text { траєкторії глобального } \\
\text { розвитку }\end{array}$ \\
\hline
\end{tabular}

Джерело: узагальнено авторами на основі [14]

вимірі (вартість 1 млрд. дол і більше), але й на якісному (інноваційно-креативна бізнес-модель, зміна глобальної технологічної парадигми, висококвалісріковані управлінці та інші аспекти). Аналіз регіонального аспекту розміщення компаній-єдинорогів дозволив виокремити як країнлідерів - а саме США, Китай, Індію, Велику Британію та Німеччину, так і глобальні міста 3 найбільшою концентрацією компаній-єдинорогів: Сан-Франциско, Нью-Йорк, Пекін, Лондон та ряд інших міст, які в переважній більшості відносяться до високо інтегрованих міст катеropiï Alpha та Beta. Найбільш привабливими секторами діяльності компаній-єдинорогів залишаються сектори фрінтех, програмного забезпечення та IT-послуг, електронної комерції. Ключовими трансорормаційнами викликами для розвитку компаній-єдинорогів у часи пандемії COVID-19 виділено споживання з дому, роботу з дому та навчання з дому. Саме ці виклики стали стартовою платформою для активізації розвитку компаній в окремих галузях та секторах.

\section{СПИСОК ВИКОРИСТАНИХ ДЖЕРЕЛ:}

1. Lee A. Welcome To The Unicorn Club: Learning From Billion-Dollar Startups. Techcrunch, 2013. URL: https://techcrunch.com/2013/11/02/welcome-to-the-unicorn-club/ (дата звернення: 10.08.2021).

2. The unicorn club, 2021. URL: https://app.dealroom.co/unicorns/f/tags/anyof_verified\%20unicorns\%20and\% 20\%241b\%20exits_verifiedunicornsand1bexits (дата звернення: 08.08.2021).

3. The Complete List Of Unicorn Companies. Cbinsights, 2021. URL: https://www.cbinsights.com/researchunicorn-companies (дата звернення: 10.08.2021).

4. Callery J. Determining True Unicorn Startups. State University of New York College at Brockport. 2020. Senior Honors Theses 283. C. 1-42.

5. Офіційний сайт компанії Bytedance. URL: https://bytedance.com/en/ (дата звернення: 09.08.2021).

6. Офіційний сайт компанії Stripe. URL: https://stripe.com (дата звернення: 09.08.2021).

7. Офіційний сайт компанії Spacex. URL: https://www.spacex.com (дата звернення: 09.08.2021).

8. The factory of the future. Industry 4.0 - the challenges of tomorrow: KPMG. 2016 URL: https://assets.kpmg.com/ content/dam/kpmg/pdf/2016/05/factory-future-industry-4.0.pdf (дата звернення: 10.08.2021). 
9. D. Rook, A. Salvatori, J. van Moyland, P. Rosa. Innovation Patterns: Upgrading Sectoral Classification for the Fourth Industrial Revolution. Kensho Technologies. 2017. № 7. P. 1-24.

10. Hodgson L. Europe's unicorn herd grows bigger and faster in 2021. Pitchbook. 2021. URL: https://pitchbook.com/ news/articles/europes-unicorn-herd-grows-bigger-and-faster-in-2021 (дата звернення: 11.08.2021).

11. Пирог О.В., Максимчук Я.С. Концептуальні засади глобальних міст: наукові підходи до визначення сутності. Вісник Дніпропетровського університету. Серія : Світове господарство і міжнародні економічні відносини. 2017. Т. 25. Вип. 9. С. 59-69. URL: http://nbuv.gov.ua/UJRN/Sv_g_2017_25_9_7 (дата звернення: 11.08.2021).

12. The World According to GaWC 2020. Globalization and World Cities (GaWC) Research Network, 2020. URL: https://www.lboro.ac.uk/gawc/world2020t.html (дата звернення: 12.08.2021).

13.Зайцева Л.О. Капіталізація як показник ефективної діяльності компанії : Збірник тез міжнародної науково-практичної конфреренції «розвиток і впровадження технологій у виробництві» (12-13 березня 2021 рік). Нідерланди, 2021. С. 22-26.

14. Tech unicorns and COVID-19 Inside versus outside unicorns. Deloitte, 2020. URL: https://www2.deloitte.com/ content/dam/Deloitte/global/Documents/Technology-Media-Telecommunications/gx-tmt-tech-unicorns.pdf (дата звернення: 12.08.2021).

15. China Unicorn Survey. PwC. 2019. URL: https://www.pwc.com/gx/en/industries/assets/pwc-unicorns-survey.pdf (дата звернення: 12.08.2021).

\section{REFERENCES:}

1. Lee A. (2013). Welcome To The Unicorn Club: Learning From Billion-Dollar Startups. Techcrunch. Available at: https://techcrunch.com/2013/11/02/welcome-to-the-unicorn-club/ (accessed 10 August 2021).

2. The unicorn club (2021). Available at: https://app.dealroom.co/unicorns/f/tags/anyof_verified\%20unicorns\%20 and $\% 20 \% 241 \mathrm{~b} \% 20$ exits_verifiedunicornsand1bexits (accessed 8 August 2021).

3. The Complete List Of Unicorn Companies. Cbinsights (2021). Available at: https://www.cbinsights.com/ research-unicorn-companies (accessed 10 August 2021).

4. Callery J. Determining True Unicorn Startups (2020). State University of New York College at Brockport. Senior Honors Theses 283. P. 1-42.

5. Official web-site of Bytedance. Available at: https://bytedance.com/en/ (accessed 9 August 2021).

6. Official web-site of Stripe. Available at: https://stripe.com (accessed 9 August 2021).

7. Official web-site of Spacex Available at: https://www.spacex.com (accessed 9 August 2021).

8. The factory of the future. Industry 4.0 - the challenges of tomorrow: KPMG (2016). Available at: https://assets.kpmg.com/content/dam/kpmg/pdf/2016/05/factory-future-industry-4.0.pdf (accessed 10 August 2021).

9. D. Rook, A. Salvatori, J. van Moyland, P. Rosa (2017). Innovation Patterns: Upgrading Sectoral Classification for the Fourth Industrial Revolution. Kensho Technologies, no. 7, pp. 1-24.

10. Hodgson L. Europe's unicorn herd grows bigger and faster in 2021. Pitchbook. 2021. Available at: https://pitchbook.com/news/articles/europes-unicorn-herd-grows-bigger-and-faster-in-2021 (accessed 11 August 2021).

11. Pyrog O., Maksymchuk Ya. (2017). Konceptualni zasady globalnyh mist: naukovi pidhody do vyznachennya sutnosti [Conceptual bases of global cities: scientific approaches to the defining of the essence]. Visnyk Dnipropetrovskogo universytetu, vol. 25, issue 9, pp. 59-69. Available at: http://nbuv.gov.ua/UJRN/Sv_9_2017_25_9_7 (accessed 11 August 2021).

12. The World According to GaWC 2020. Globalization and World Cities (GaWC) Research Network, 2020. Available at: https://www.lboro.ac.uk/gawc/world2020t.html (accessed 12 August 2021).

13. Zaitseva L.O. (2021) Kapitalizatsiya yak pokaznyk efektyvnoi diyalnosti kompaniyi [Capitalization as an indicator of a company`s effective activity]: Zbirnyk tez mighnarodnoi naukovo-practichnoi conferenciyi "Rozvytok I vprovadgennya tehnologii u vyrobnyctvi" (12-13 bereznya 2021). Netherland, pp. 22-26.

14. Tech unicorns and COVID-19 Inside versus outside unicorns. Deloitte, 2020. Available at: https://www2.deloitte.com/content/dam/Deloitte/global/Documents/Technology-Media-Telecommunications/ gx-tmt-tech-unicorns.pdf (accessed 12 August 2021).

15. China Unicorn Survey. PwC. 2019. Available at: https://www.pwc.com/gx/en/industries/assets/pwcunicorns-survey.pdf (accessed 12 August 2021). 